\title{
WATER, SANITATION AND ITS IMPACT ON ENVIRONMENT AND HUMAN BEING - A CASE STUDY
}

\author{
Harcharan Singh RUMANA * and Ramesh Chandra SHARMA ** \\ * Govind Sustainability Solution Pvt. Ltd. Unit 17-18, CSC. Pkt-E, Mayur, Vihar, Ph-II, Delhi 91, India, \\ IN-110091, hsrumana@gmail.com \\ ** Desert Medicine Research Centre (ICMR), New Pali Road, Jodhpur, Rajasthan, India, IN-342005, \\ rcsharma@hotmail.com
}

DOI: 10.2478/trser-2019-0016

KEYWORDS: drinking water quality, microbial contamination, human health, India.

\section{ABSTRACT}

The present study was carried out to assess the drinking water quality, hygiene and human health existing in the city of Jodhpur. About $89.8 \%$ of houses use household drinking water from supply, and the remaining $10.2 \%$ houses depend on public taps or other water sources. Similar results for sanitation and hygiene observed as $97 \%$ of houses did not have any garbage disposal facility and in all $10.6 \%$ did not have easy access to a sanitary facility. The results of physical and chemical parameters of ground water were above the drinking water standards, whereas in the case of household drinking water were within standard limits. The presence of total coliform, faecal coliform and faecal streptococci were showing water contamination which may be the cause of significant prevalence $5.0 \%(\mathrm{p}<0.001)$ of gastrointestinal infections.

ZUSAMMENFASSUNG: Wasser, Gesundheitspflege und ihre Auswirkungen auf die Umwelt und die Menschen - eine Fallstudie.

Vorliegende Untersuchung wurde durchgeführt, um die Qualität des Trinkwassers sowie von Hygiene und Gesundheit der in Jodhpur, lebenden Menschen zu bewerten. Etwa 89.8\% der Haushalte benutzen Trinkwasser aus der Wasserversorgung, während die verbleibenden $10.2 \%$ von öffentlichen Wasserhähnen oder anderen nicht etablierten Wasserquellen abhängig sind. Ähnliche, für die Gesundheitsversorgung und Hygiene festgestellte Ergebnisse belegen, dass $97 \%$ der Haushalte keine Einrichtungen für Abfallbeseitigung und insgesamt 10.6\% der Haushalte keinen leichten Zugang zu Sanitäranlagen haben. Die Ergebnisse von physikalischen und chemischen Parametern des Grundwassers liegen höher als die Trinkwasserstandardwerte, während sie im Falle des Haushalt Trinkwassers innerhalb der Standardgrenzen liegen. Das Vorhandensein der Gesamtkolibakterien, der Fäkalkolibakterien und Fäkal Streptokokken zeigen die Wasserkontaminierung an, die gegebenenfalls die Ursache einer bemerkenswerten Prävalenz von $5.0 \%(\mathrm{p}<0.001)$ gastrointestinaler Infektionen sind.

REZUMAT: Apa, igiena și impactul lor asupra mediului și a populației - studiu de caz.

Acest studiu a evaluat calitatea apei potabile, a igienei și sănătății populației în orașul Jodhpur. Aproape $89.8 \%$ din gospodării folosesc apa potabilă de la rețeaua de alimentare cu apă, $10.2 \%$ de la robinete publice sau alte surse. Rezultate privind îngrijirea sănătății și igiena, arată că 97\% dintre gospodării nu au facilități pentru deșeurile menajere și $10.6 \%$ nu au acces ușor la facilități sanitare. Valorile parametrilor fizici și chimici a apei freatice sunt mai mari decât standardele admise pentru apa potabilă, iar în cazul apei potabile a gospodăriilor aceste valori sunt între limitele standardului. Prezența colibacililor totali, a celor fecali și a streptococilor fecali, indică o contaminare a apei, care probabil este cauza prevalenței de $5.0 \%(\mathrm{p}<0.001)$ a infecțiilor gastro-intestinale. 


\section{INTRODUCTION}

The needs of safe water supply, sanitation and hygiene are all unable to keep pace with urban growth followed by poor housing, poor drainage and garbage accumulation causes serious pollution problems. It finally has adverse effects on the health of people (Hutton et al., 2007; WHO, 2007; Kumar et al., 2011). The problem is aggravated due to the discharge of industrial effluents containing toxic pollutants, city sewage and overproduction of solid waste, which are the main cause of most waterborne diseases (CPCB, 2009). Toxic substances such as arsenic, lead, cadmium, nitrates, pesticides, etc., also enter the household drinking water supply at many points before reaching the tap, are also a matter of concern (Morris, 1995). Lack of hygiene further aggravates the problem. The magnitude of waterborne diseases such as cholera, diarrhoea, hepatitis, typhoid, amoebic, and bacillary dysentery are very high throughout the world (WHO, 2005). Nearly half the world's population does not have access to safe water through a household connection or a yard tap from a piped distribution system and live without sanitation (WHO/UNICE, 2000). In developing countries, over $90 \%$ of all diarrhoeal deaths occur in children under five years. Improving the drinking water quality, and providing enough water, for both personal and domestic hygiene are keys to prevention and control of diarrhoeal diseases (Fewtrell et al., 2005).

Water is one of the most priceless resource of Earth and under constant and variate anthropogenic impact (Vörösmarty et al., 2000; Flörke et al., 2013; Haddeland et al., 2013; Hutton and Chase, 2017). The needs of safe water supply, sanitation and hygiene are all unable to keep pace with urban growth followed by poor housing, poor drainage and garbage accumulation, and cause serious pollution problems (Mara, 2003; Hutton and Haller, 2004; Hutton et al., 2007; Gjyli and Mukli, 2009; Mara et al., 2010). It finally has adverse effects on the health of people (Ahern et al., 2005; Gerba, 2009; Kumar et al., 2011; Lim et al., 2012; Benova et al., 2014; Pepper et al., 2015).

The urban population has increased in India three and half times (UN, 2001), from $17.28 \%$ (1951) to $28 \%$ (2001). Clean drinking water facility through taps is available to only $35 \%$ of urban households and 18\% of rural households in India as per the records of Registrar General and Census Commissioner of India 2001. Other residents use improper water sources like wells, ponds, and rivers. Lack of water, sanitation, and hygiene results in the loss of 0.4 million lives annually in India (WHO, 2007).

In the west sector of Rajasthan, which contain a sector of the Thar Desert, the situation evolves in a bad one due to a deficiency of secure water for drinking. Jodhpur area (Rajasthan, India) includes over one million residents with $2.1 \%$ annual human population increase as per census 2001. It has over 10,000 industrial sites, which induce pollution and influence the water quality. The studied locality has a complex system of pipelines for water supply and sewerage fluids, which does not support all the needs of the inhabitants and require numerous restorations. There is scarce available information in the present in India, concerning the drinking water pollution and its negative human's health effects. Thus, this study was developed to evaluate the significance of water pollution, sanitation problem, occurrence and predominance of diseases that may guide in planning and managing intervention activities.

Increasing urban population from about 869,403 to 972,259 and industries from 8,468 to 10,585 during the last five years, caused concern for increasing water pollution. The studied city has incomplete and inadequately maintained sewerage and water distribution system. 


\section{MATERIAL AND METHODS}

Study area. Jodhpur the Sun City is placed in a dry region in the west of Rajasthan, where economic advancement was registered as very important since the last decade. Jodhpur has developed into the second biggest city of Rajasthan area and an outstanding centre both for industry and education. It is placed at latitude $26^{\circ} 18^{\prime} \mathrm{N}$, longitude $73^{\circ} 04^{\prime} \mathrm{E}$ and at an elevation of $230 \mathrm{~m}$ above m.s.l. and cover a total area of $70 \mathrm{~km}^{2}$. Placed at the margin of the Thar Desert the researched surface where there is acute dryness with very hot summers, with temperatures around $45^{\circ} \mathrm{C}$, with numerous dust storms and moderate temperature in winter. The annual ordinary rainfall is $31.0 \mathrm{~mm}$. Jodhpur continue to be one of the fastest developing cities in India.

Water sampling sites. The city has 60 wards with different landscapes (Fig. 1). Public Health Engineering Department (PHED) treats this water in waterworks and then supply the city for drinking purpose. Water samples were collected from following major categories of sites. Category one: the household drinking water samples were collected from twelve randomly selected sites in the city as shown in figure 1. Category two: similarly groundwater samples from open wells, step wells, tube wells and hand pumps were also collected from the twelve sites (Fig. 1). Category three: there are three main reservoirs of raw water in the city, Kailana, Takhat Sagar, and Balsamand. These reservoirs receive water continuously from the Rajiv Gandhi Canal. These water sources also receive runoff water from the adjoining watersheds during rains. Category four: waterworks water samples were also collected for comparative study. The main water works for drinking water supply to the city is set up at Kaylana Lake, Chopasani Road. The other one is at Balsamand Lake, which supplies water to a very small population of the city in its north. Samples were collected since 2004 to 2005, covering all seasons.

Collection of water sample. Water samples of various potable water sources as household drinking water and ground waters (open wells, tube wells, hand pumps, etc.) were collected in screw-capped, clean, sterile, 2.5-litre inert plastic containers (PVC bottles) from the selected sites. Immediately after collection of samples, bottles were put in an icebox and were transported to the laboratory. Samples are stored at $4^{\circ} \mathrm{C}$ to avoid any changes in their physical, chemical, and biochemical characteristics. For the microbial investigations samples were collected separately in sterile $500 \mathrm{~mL}$ bottles and analyzed within 30 hours.

Water analysis. Water quality was determined for physical, chemical, and bacteriological characteristics. Parameters measured for water pollution studies include $\mathrm{pH}$, temperature, turbidity, conductivity and total dissolved solids (TDS), alkalinity, hardness, chlorides, fluorides, nitrates, phosphates, and sulphates for chemical, lead, cadmium, iron, dissolved oxygen, biological oxygen demand-BOD, total coliforms (TC), faecal coliform (FC) and faecal streptococci (FS). The levels of heavy metals were determined by acid digestion methods using Atomic Absorption Spectrophotometer (Perkin-Elmer Model 2380) and air-acetylene flame. The bacteriological investigation was carried out by the membrane filtration method. Direct plating and estimation of coliform densities were done. The coliform density was reported as membrane filtration count per $100 \mathrm{~mL}$. The standard methodology was followed for water pollution assessment (APHA, 1992, 1998). 


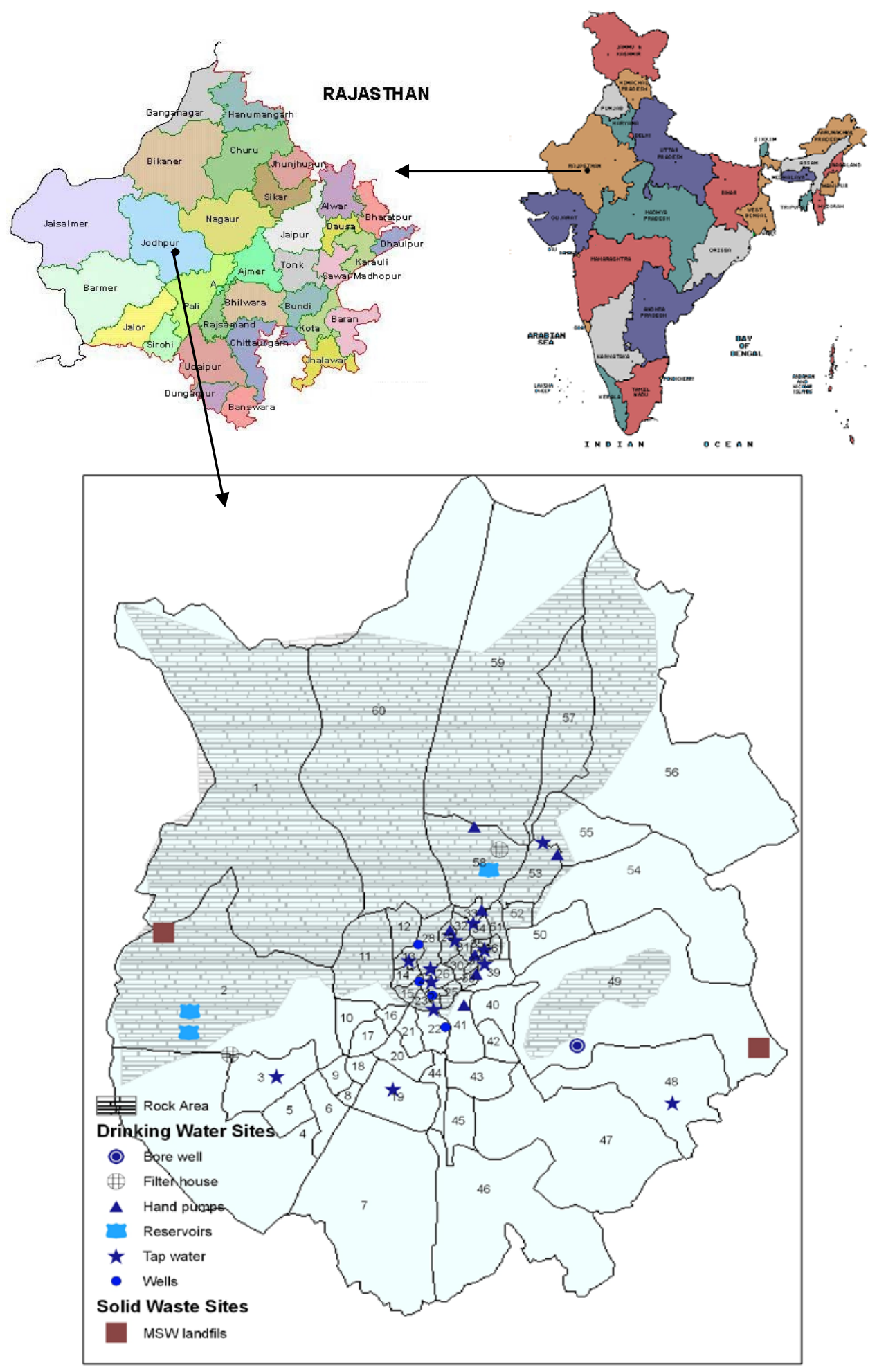

Figure 1: Ward map showing the drinking water pollution and solid wastes study sites in Jodhpur, Rajasthan, India. 
Sanitation issue. The most common method of disposal of municipal solid wastes in the city is by deposition in landfills. There are two dumping places in the city for municipal solid wastes. The main dumping ground for Municipal Solid Waste (MSW) is situated in the western part of the city near the Kaylana Reservoir. The municipal solid waste dumping area is spread over a large area of about 200 acres of lands in the western part of the city on a hilly and stony bed. The samples have been collected from the sites on a random basis to take an unbiased representative sample. Two main landfills or disposal sites have been selected for the present study (Fig. 1). For taking the solid and hazardous wastes samples from the selected sites, a one-two $m$ diameter deep ditch was made with an area of about two $\mathrm{m}^{2}$ from the surface of the landfills. The samples were analysed using standard methods as described in Laboratory Manual for Soil and Water Testing Methods (Ghosh et al., 1983).

Health survey. A human population cross-sectional health analysis was accomplished in the city. A sample size of 10,000 was taken to find out the prevalence of morbidity circumstances with a prevalence of $1 \%$ or over, with a $10 \%$ standard error. The samples were dispersed to 60 wards of Jodhpur. Data on local water-associated health problems as per the schedule at household level were collected. The information about the number of humans treated at OPD and wards of four teaching hospitals of Jodhpur regarding gastrointestinal illnesses and cancer were collected from office of Principal Dr. S. N. Medical College, Jodhpur. Exhaustive investigation of information about health and illnesses and their link with diverse water pollution has been achieved using Epi Info 2000 software.

\section{RESULTS}

Water quality. A total of 165 representative water samples were collected from different localities of the city. Out of 165 water samples, 123 were from household drinking water, six from the outlet of waterworks, nine from surface water sources and 36 from ground waters (open wells, step wells, hand pumps and tube wells) were collected. They were examined for physical, chemical, and bacteriological parameters and results of annual average water quality with the number of samples above the drinking water standards are described in tables 1-2. Drinking water samples collected from waterworks showed most of the parameters were within acceptable limits. Very few samples from household drinking water were reported outside the standards for their physical and chemical factors (Tab. 2). Only a few colonies of total coliform, faecal coliform and faecal streptococci bacteria were present. The results of water samples collected from surface waters (reservoirs/lakes) for most of physical and chemical parameters were found within the range of drinking water standards except turbidity (Tab. 1). The growth of all three types of colonies of bacteria as total colilfom, faecal coliform and faecal streptococci in these untreated water samples were observed (Tabs. 1-2).

Groundwater is also used for drinking as well as other activities such as bathing, washing, cleaning, etc. The results of physical, chemical, and bacteriological characteristics of groundwater samples are given in table 1 . The parameters such as conductivity, total dissolved solids, total hardness, nitrates, alkalinity, dissolved oxygen, total coliform, faecal coliform, and fecal streptococci in groundwater samples were found above the acceptable standard limits. The annual average level of these parameters was also found above the acceptable standards. The results of metal analysis show that lead, iron, and cadmium in all water samples were present in traces or below the detectable limit. The growth of colonies of total coliform, faecal coliform and fecal streptococci bacteria were found in all type of water samples. 
Table 1: Annual average values of physical-chemical and bacteriological characteristics of different water sources (2004-2005); * values in mg/l; ** bacterial colonies as counts/ $100 \mathrm{ml}$; Turb. - turbidity (NTU), cond. ( $\mu \mathrm{S} / \mathrm{cm})$, Hard. - hardness, Res. $\mathrm{Cl}^{*}$ - Residual Cl*.

\begin{tabular}{|c|c|c|c|c|c|c|}
\hline 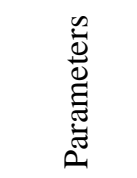 & $\begin{array}{l}\frac{0}{0} \\
\frac{\pi}{0} \\
\frac{0}{2}\end{array}$ & 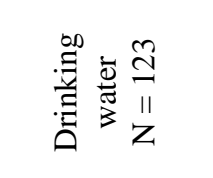 & 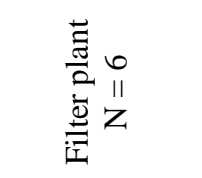 & 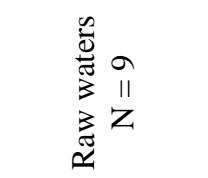 & 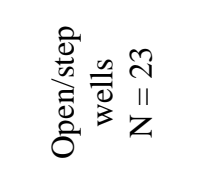 & 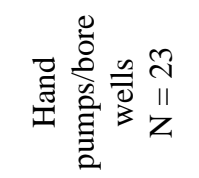 \\
\hline $\mathrm{pH}$ & $6.5-8.5$ & $7.6+0.34$ & $7.4+0.3$ & $7.6+0.26$ & $7.6+0.23$ & $7.5+0.3$ \\
\hline Turb. & $<5.0$ & $1.2+0.93$ & $1.7+1.5$ & $18.4+14.4$ & $0.8+1.05$ & $3.3+3.9$ \\
\hline Cond. & $<600$ & $256.6+118.58$ & $450.7+302.0$ & $425.3+267.17$ & $1079.1+341.6$ & $1820.2+988.9$ \\
\hline TDS* & $<500$ & $139.9+59.31$ & $153.0+20.3$ & $207.1+69.6$ & $702.1+196.28$ & $1256.8+670.9$ \\
\hline Hard.* & $<300$ & $95.2+22.12$ & $132.5+32.7$ & $143.9+52.6$ & $270.8+43.35$ & $393.2+230.6$ \\
\hline Res. Cl* & $<0.20$ & $0.1+0.04$ & $0.2+0.1$ & $0.1+0.04$ & $0.1+0.03$ & $0.1+0.0$ \\
\hline T. $\left({ }^{\circ} \mathrm{C}\right)$ & NA & $25.1+7.62$ & $24.7+5.0$ & $24.6+6.89$ & $25.1+2.21$ & $25.1+2.0$ \\
\hline $\mathrm{Cl}^{*}$ & $<250$ & $32.7+8.24$ & $39.9+23.9$ & $43.8+49.52$ & $93.9+38.08$ & $209.5+110.8$ \\
\hline $\mathrm{F}^{*}$ & $<1.0$ & $0.1+0.10$ & $0.7+0.6$ & $0.7+0.58$ & $0.2+0.12$ & $0.7+0.4$ \\
\hline $\mathrm{NO}_{3} *$ & $<45$ & $9.3+11.89$ & $5.1+2.8$ & $6.4+4.09$ & $124.6+57.72$ & $296.1+167.9$ \\
\hline $\mathrm{SO}_{4} *$ & $<200$ & $39.8+29.01$ & $49.0+22.3$ & $73.2+35.37$ & $146.3+69.67$ & $202.3+127.4$ \\
\hline Alk.* & $<200$ & $97.3+44.70$ & $87.9+44.0$ & $132.1+39.80$ & $272.2+102.67$ & $302.6+124.5$ \\
\hline DO* & $>7.5$ & $6.0+1.01$ & $5.5+0.8$ & $5.3+0.77$ & $4.4+2.02$ & $4.5+1.8$ \\
\hline BOD* & $<2.0$ & $1.0+0.51$ & $0.9+0.6$ & $1.0+0.97$ & $1.1+0.75$ & $1.1+0.6$ \\
\hline $\mathrm{Pb}^{*}$ & $<0.05$ & $0.0+0.00$ & $0.0+0.00$ & $0.0+0.00$ & $0.0+0.00$ & $0.0+0.0$ \\
\hline $\mathrm{Fe}^{*}$ & $<0.30$ & $0.1+0.08$ & $0.2+0.10$ & $0.2+0.09$ & $0.2+0.21$ & $0.2+0.2$ \\
\hline $\mathrm{Cd}^{*}$ & $<0.01$ & $0.0+0.05$ & $0.0+0.00$ & $0.0+0.00$ & $0.0+0.00$ & $0.0+0.0$ \\
\hline
\end{tabular}

Table 2: Number of water samples outside the acceptable standard (2004-2005); *Values are in $\mathrm{mg} / \mathrm{l} ; * *$ Bacterial colonies as counts/100 mL.

\begin{tabular}{|c|c|c|c|c|c|c|c|c|c|}
\hline \multirow[b]{2}{*}{ 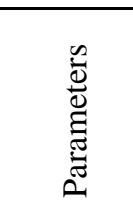 } & \multirow[b]{2}{*}{ 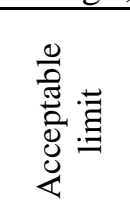 } & \multirow[b]{2}{*}{ 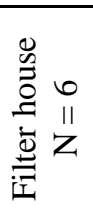 } & \multicolumn{4}{|c|}{ Drinking tap water } & \multirow[b]{2}{*}{ 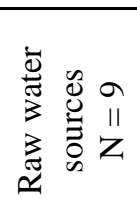 } & \multirow[b]{2}{*}{ 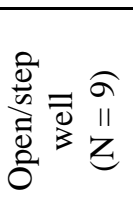 } & \multirow[b]{2}{*}{ 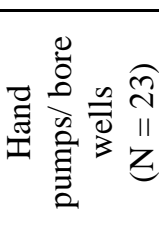 } \\
\hline & & & 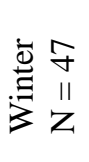 & 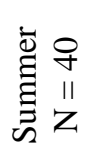 & 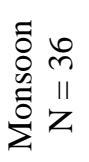 & 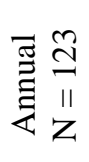 & & & \\
\hline $\mathrm{pH}$ & $6.5-8.5$ & 0 & 0 & 8 & 2 & 10 & 1 & 0.0 & 1.0 \\
\hline Turb. & $<5.0$ & 0 & 0 & 0 & 1 & 1 & 7 & 0.0 & 3.0 \\
\hline Cond. & $<600$ & 0 & 2 & 2 & 0 & 4 & 2 & 9.0 & 22.0 \\
\hline TDS* & $<500$ & 0 & 1 & 0 & 0 & 1 & 0 & 8.0 & 22.0 \\
\hline Hard.* & $<300$ & 0 & 0 & 0 & 0 & 0 & 0 & 3.0 & 15.0 \\
\hline Res. Cl* & $\begin{array}{c}<0.20 \\
\end{array}$ & 0 & 0 & 0 & 0 & 0 & 0 & 0.0 & 0.0 \\
\hline T. $\left({ }^{\circ} \mathrm{C}\right)$ & NA & 0 & 0 & 0 & 0 & 0 & 0 & 0.0 & 0.0 \\
\hline $\mathrm{Cl}^{*}$ & $<250$ & 0 & 0 & 0 & 0 & 0 & 0 & 0.0 & 8.0 \\
\hline $\mathrm{F}^{*}$ & $<1.0$ & 0 & 0 & 0 & 0 & 0 & 3 & 0.0 & 5.0 \\
\hline $\mathrm{NO}_{3} *$ & $<45$ & 0 & 2 & 0 & 0 & 2 & 0 & 9.0 & 22.0 \\
\hline $\mathrm{SO}_{4} *$ & $<200$ & 0 & 0 & 0 & 0 & 0 & 0 & 1.0 & 12.0 \\
\hline Alk.* & $<200$ & 0 & 1 & 0 & 0 & 1 & 0 & 7.0 & 19.0 \\
\hline$\overline{\mathrm{DO} *}$ & $>7.5$ & 0 & 47 & 40 & 36 & 123 & 8 & 9.0 & 21.0 \\
\hline BOD* & $<2.0$ & 0 & 1 & 0 & 1 & 2 & 1 & 2.0 & 1.0 \\
\hline TC** & 0.0 & 6 & 34 & 38 & 35 & 107 & 8 & 7.0 & 22.0 \\
\hline FC** & 0.0 & 0 & 18 & 25 & 26 & 69 & 7 & 6.0 & 15.0 \\
\hline$\overline{F S^{* *}}$ & 0.0 & 0 & 14 & 16 & 21 & 51 & 7 & 6.0 & 9.0 \\
\hline
\end{tabular}


Sanitation issue. Removal of waste is a main problem of worry. Municipal Corporation gathers wastes and transports to the disposal sites, which are commonly a low-lying surface on the periphery of the city. The data about it was obtained from Jodhpur Municipal Corporation. Jodhpur Municipal Corporation gathers city solid wastes in open trucks, which cannot compress the wastes. About 30-35 trucks, of 10 tons each, of solid wastes are gathered and transported to the dumping areas. The principal dumping area is located near Badli in the western part of the city. This is located in the basin area of Kaylana, the main water reservoir of Jodhpur. The city solid waste dumping field is spread over a broad area of about 200 acres in the western side of the city on hilly and stony substrata. The main dumping area is under the expanding state of motorized machinery for compacting and levelling the wastes, and covering the top level with soil before finally compacting it. Solid waste fragments were sampled from these landfills, and separated into its contents. The principal elements were minerals, coal, vegetables, paper, glass, rags, wood, plastics, iron, rubber, dust, etc., which may be rich in toxic chemicals and also pathogens. The organic matter was isolated. The percentage fractions of each element of municipal solid wastes samples are presented in table 3.

Table 3: Percentage and average weight of municipal solid waste fractions.

\begin{tabular}{|l|c|c|}
\hline \multirow{2}{*}{ Components } & \multicolumn{2}{|c|}{ Average (n = 12) } \\
\cline { 2 - 3 } & Weight in grams & $\%$ \\
\hline Minerals and building materials (mixed) & $1,661.4$ & 33.2 \\
\hline Polythene bags and plastics (mixed) & 136.2 & 2.7 \\
\hline Glasses and porcelains (mixed) & 130.3 & 2.6 \\
\hline Fibers (textile and a part of waste wood) & 112.3 & 2.3 \\
\hline Metal: iron (mixed) & 73.5 & 1.5 \\
\hline Total compostable material & 1,280 & 25.6 \\
\hline Fine soil & $1,606.3$ & 32.1 \\
\hline Total weight & 5,000 & 100.0 \\
\hline
\end{tabular}

\section{Health Assessment}

Health survey was conducted in 1,600 houses in the city, which included 9,287 individuals (46.2\% females and 53.8\% males). Out of 9,287 individuals, 81.1\% were Hindus, $18.2 \%$ were Muslims, $0.5 \%$ were Sikhs and $0.2 \%$ were Christians. Based on their housing details, $2.9 \%$ of individuals were slum dwellers (lowest income group), $46.7 \%$ lived in lowincome settlement, $47.3 \%$ in middle-income settlement and 3\% lived in posh colonies (highincome settlement). Educational status of the population shows that $24.0 \%$ population $(17.4 \%$ males and 31.7\% females) was illiterate and 76\% literate. Most houses (97\%) did not have any garbage disposal facility, and garbage from these houses was dumped on roadsides or open plots. It was found that toilets were not available in 5.9\% houses and these residents practiced open field defecation, whereas $0.1 \%$ individuals depended on common toilets meant for a group of families, $1.3 \%$ on dry pits and $3.3 \%$ on public toilets. In all $10.6 \%$ of houses in the city did not have easy access to sanitary facilities. Tap water supply was available to $85.6 \%$ population (89.8\% houses), and the remaining $14.4 \%$ population (10.2\% house) depended on public taps/tankers, hand pumps, reservoirs, bore wells and open wells. 
The percent prevalence of different environmental related diseases such as gastrointestinal diseases, diabetes mellitus and skin diseases are described in tables 4-6. The prevalence of gastrointestinal infections was $5.0 \%$ (Tab. 4). It was $4.9 \%$ in males and $4.7 \%$ of females. Of all $1.2 \%$ had abdominal pain, $0.4 \%$ loss of appetite, $0.8 \%$ hyperacidity, $0.3 \%$ diarrhoea, $0.3 \%$ dysentery, $0.7 \%$ gastritis, $0.3 \%$ hepatitis, $0.6 \%$ jaundice and $0.4 \%$ has typhoid. In the survey, $2.1 \%$ males and $2.2 \%$ of females have shown a history of diabetes (Tab. 5). Percent prevalence of skin diseases was $4.1 \%$ (Tab. 6). Prevalence of various skin diseases such as allergic manifestation, fungal infections, dermatitis, leucoderma and patch of discolouration were $3.0,0.3,0.8,0.2$, and $0.3 \%$ respectively.

Table 4: Percent prevalence of gastrointestinal diseases in Jodhpur.

\begin{tabular}{|c|c|c|c|c|c|c|c|c|c|c|c|c|}
\hline \multirow[b]{2}{*}{ 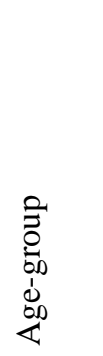 } & \multirow[b]{2}{*}{ ஸे } & \multirow[b]{2}{*}{ 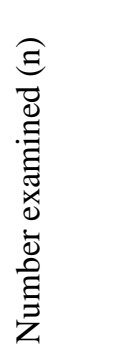 } & \multicolumn{10}{|c|}{ Percent prevalence of } \\
\hline & & & 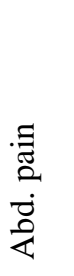 & 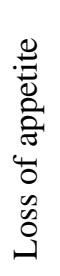 & 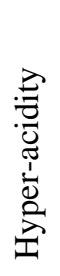 & 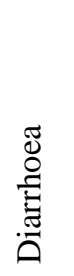 & 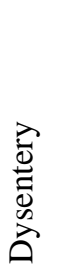 & 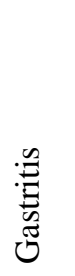 & 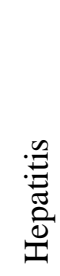 & 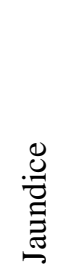 & 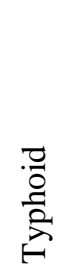 & 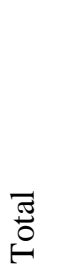 \\
\hline \multirow{3}{*}{$0-1$} & $\mathrm{M}$ & 42 & 2.4 & 0.0 & 0.0 & 2.4 & 0.0 & 0.0 & 0.0 & 2.4 & 0.0 & 7.2 \\
\hline & $\mathrm{F}$ & 31 & 0.0 & 0.0 & 0.0 & 0.0 & 0.0 & 0.0 & 0.0 & 0.0 & 0.0 & 0.0 \\
\hline & $\mathrm{M}+\mathrm{F}$ & 73 & 1.4 & 0.0 & 0.0 & 1.4 & 0.0 & 0.0 & 0.0 & 1.4 & 0.0 & 4.2 \\
\hline \multirow{3}{*}{$1-5$} & $\mathrm{M}$ & 305 & 0.3 & 0.7 & 0.0 & 2.3 & 1.0 & 2.3 & 0.0 & 1.3 & 0.0 & 7.9 \\
\hline & $\mathrm{F}$ & 258 & 0.4 & 0.0 & 0.4 & 1.2 & 0.8 & 1.6 & 0.0 & 0.8 & 0.4 & 5.6 \\
\hline & $\mathrm{M}+\mathrm{F}$ & 563 & 0.4 & 0.4 & 0.2 & 1.8 & 0.9 & 2.0 & 0.0 & 1.1 & 0.2 & 7.0 \\
\hline \multirow{3}{*}{$5-14$} & $\mathrm{M}$ & 967 & 1.4 & 0.3 & 0.2 & 0.4 & 0.7 & 0.6 & 0.1 & 1.0 & 0.4 & 5.1 \\
\hline & $\mathrm{F}$ & 802 & 2.1 & 0.4 & 0.0 & 0.4 & 0.5 & 0.6 & 0.2 & 0.5 & 0.6 & 5.3 \\
\hline & $\mathrm{M}+\mathrm{F}$ & 1,769 & 2.0 & 0.3 & 0.1 & 0.4 & 0.6 & 0.6 & 0.2 & 0.8 & 0.5 & 5.5 \\
\hline \multirow{3}{*}{$15-44$} & $\mathrm{M}$ & 2,581 & 0.9 & 0.2 & 0.6 & 0.1 & 0.3 & 0.7 & 0.3 & 0.8 & 0.4 & 4.3 \\
\hline & $\mathrm{F}$ & 2,226 & 1.1 & 0.6 & 0.9 & 0.2 & 0.1 & 0.4 & 0.3 & 0.2 & 0.4 & 4.2 \\
\hline & $\mathrm{M}+\mathrm{F}$ & 4,807 & 1.0 & 0.4 & 0.7 & 0.1 & 0.2 & 0.6 & 0.3 & 0.5 & 0.4 & 4.2 \\
\hline \multirow{3}{*}{ 45-59 } & $\mathrm{M}$ & 695 & 0.7 & 0.3 & 1.7 & 0.0 & 0.4 & 0.8 & 0.6 & 0.3 & 0.4 & 5.2 \\
\hline & $\mathrm{F}$ & 561 & 2.0 & 0.4 & 3.2 & 0.2 & 0.0 & 0.4 & 0.2 & 0.4 & 0.4 & 7.2 \\
\hline & $M+F$ & 1,256 & 1.3 & 0.3 & 2.4 & 0.1 & 0.2 & 0.7 & 0.4 & 0.3 & 0.4 & 6.1 \\
\hline \multirow{3}{*}{$60+$} & $\mathrm{M}$ & 403 & 0.0 & 1.2 & 0.2 & 0.0 & 0.2 & 0.7 & 1.0 & 0.2 & 0.0 & 3.5 \\
\hline & $F$ & 416 & 1.0 & 0.0 & 1.7 & 1.0 & 0.5 & 0.0 & 0.2 & 0.2 & 0.0 & 4.6 \\
\hline & $M+F$ & 819 & 0.6 & 0.6 & 1.0 & 0.5 & 0.4 & 0.4 & 0.6 & 0.2 & 0.0 & 4.3 \\
\hline \multirow{3}{*}{$\begin{array}{l}\text { All } \\
\text { ages }\end{array}$} & $\mathrm{M}$ & 4,993 & 0.9 & 0.4 & 0.6 & 0.3 & 0.4 & 0.8 & 0.3 & 0.8 & 0.4 & 4.9 \\
\hline & $\mathrm{F}$ & 4,294 & 1.4 & 0.4 & 1.0 & 0.3 & 0.2 & 0.5 & 0.2 & 0.3 & 0.4 & 4.7 \\
\hline & $\mathrm{M}+\mathrm{F}$ & 9,287 & 1.2 & 0.4 & 0.8 & 0.3 & 0.3 & 0.7 & 0.3 & 0.6 & 0.4 & 5.0 \\
\hline
\end{tabular}


Table 5: Percent prevalence of known diabetics in Jodhpur.

\begin{tabular}{|l|l|c|c|}
\hline Age-group & Sex & Number examined (n) & Percent prevalence of known diabetics \\
\hline $5-14$ & $\mathrm{M}$ & 967 & 0.1 \\
\cline { 2 - 4 } & $\mathrm{F}$ & 802 & 0.1 \\
\cline { 2 - 4 } & $\mathrm{M}+\mathrm{F}$ & 1,769 & 0.1 \\
\hline \multirow{5}{*}{$45-44$} & $\mathrm{M}$ & 2,581 & 0.6 \\
\cline { 2 - 4 } & $\mathrm{F}$ & 2,226 & 0.7 \\
\cline { 2 - 4 } & $\mathrm{M}+\mathrm{F}$ & 4,807 & 0.6 \\
\hline \multirow{4}{*}{$65-59$} & $\mathrm{M}$ & 695 & 5.6 \\
\cline { 2 - 4 } & $\mathrm{F}$ & 561 & 5.7 \\
\cline { 2 - 4 } & $\mathrm{M}+\mathrm{F}$ & 1,256 & 5.7 \\
\hline \multirow{5}{*}{ All ages } & $\mathrm{M}$ & 403 & 12.4 \\
\cline { 2 - 4 } & $\mathrm{F}$ & 416 & 11.3 \\
\cline { 2 - 4 } & $\mathrm{M}+\mathrm{F}$ & 819 & 11.8 \\
\cline { 2 - 4 } & $\mathrm{F}$ & 4,993 & 2.1 \\
\cline { 2 - 4 } & $\mathrm{M}+\mathrm{F}$ & 4,294 & 2.2 \\
\hline
\end{tabular}

Table 6: Percent prevalence of skin diseases in Jodhpur.

\begin{tabular}{|c|c|c|c|c|c|c|c|c|}
\hline \multirow{2}{*}{\multicolumn{2}{|c|}{ 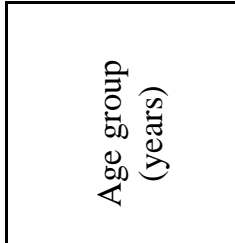 }} & \multirow[b]{2}{*}{ 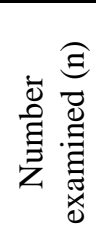 } & \multicolumn{6}{|c|}{ Percent prevalence of } \\
\hline & & & 苞 & 营.气 & 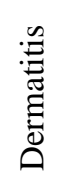 & 总 & 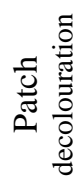 & 胥 \\
\hline \multicolumn{2}{|l|}{$0-1$} & 73 & 0.0 & 0.0 & 1.4 & 0.0 & 0.0 & 1.4 \\
\hline \multicolumn{2}{|l|}{$1-5$} & 563 & 2.7 & 0.4 & 0.2 & 0.0 & 0.0 & 3.3 \\
\hline \multicolumn{2}{|c|}{$5-14$} & 1,769 & 3.5 & 0.2 & 0.3 & 0.1 & 0.1 & 4.2 \\
\hline \multicolumn{2}{|c|}{$15-44$} & 4,807 & 2.4 & 0.3 & 0.4 & 0.1 & 0.4 & 3.6 \\
\hline \multicolumn{2}{|c|}{$45-59$} & 1,256 & 3.5 & 0.5 & 0.1 & 0.1 & 0.7 & 4.9 \\
\hline \multicolumn{2}{|c|}{$60+$} & 819 & 3.4 & 0.1 & 0.4 & 0.6 & 0.1 & 4.6 \\
\hline \multirow{3}{*}{$\begin{array}{c}\text { All } \\
\text { ages }\end{array}$} & 4,993 & 2.8 & 0.3 & 0.3 & 0.0 & 0.4 & 3.8 & - \\
\hline & 4,294 & 3.1 & 0.3 & 0.3 & 0.3 & 0.3 & 4.3 & - \\
\hline & 9,287 & 3.0 & 0.3 & 0.3 & 0.2 & 0.3 & 4.1 & - \\
\hline
\end{tabular}

Table 7: Number of Gastroenteritis diseases and cancer patients.

\begin{tabular}{|l|c|c|c|}
\hline \multirow{2}{*}{ Teaching hospitals Jodhpur } & \multicolumn{3}{|c|}{ Year } \\
\cline { 2 - 4 } & 2002 & 2003 & 2004 \\
\hline Infections of GIT & 43,813 & 39,740 & 47,700 \\
\hline Malignancies of GIT & 302 & 300 & 300 \\
\hline
\end{tabular}

Secondary data for gastrointestinal infections, gastrointestinal malignancies and leukaemia were also collected from all teaching hospitals of the city and is shown in table 7. The numbers of cases of gastrointestinal diseases were showing an increasing trend. However, there was not any trend observed for the number of cases of gastrointestinal cancer (oesophagus, stomach, and intestine) no change was observed for gastrointestinal malignancies (Fig. 2). Leukaemia also did not show an increasing trend. 


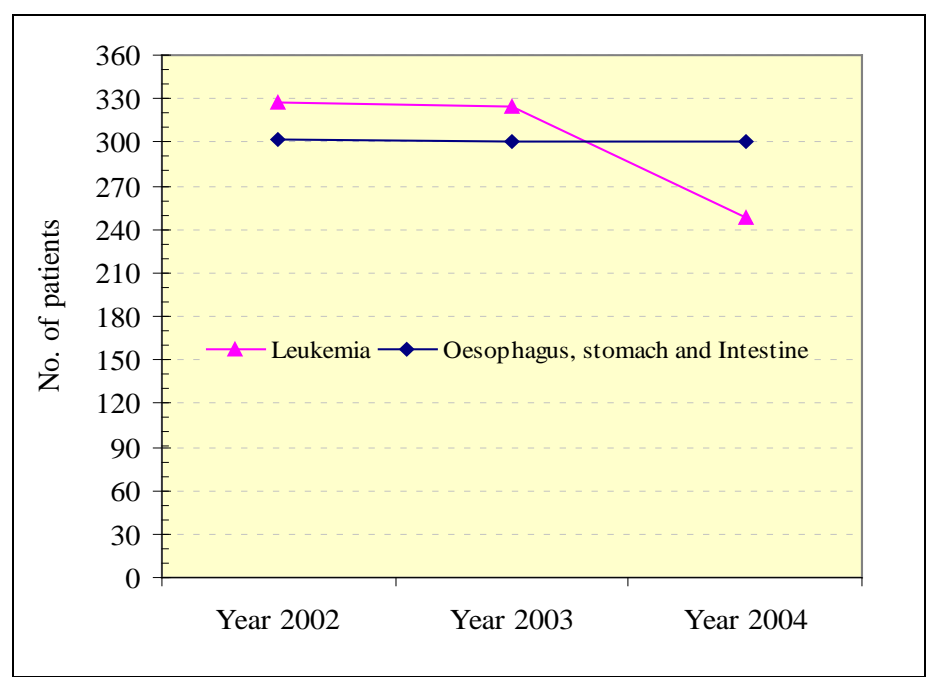

Figure 2: Number of gastrointestinal malignancies at teaching hospitals.

\section{DISCUSSION}

The absence of faecal coliform and faecal streptococci in chlorinated water at filter house outlet samples and presence of FC in 69 samples (56\%) and FS in 51 (42\%) samples of household drinking water (Tabs. 1-2) indicates contamination of water during its flow in the supply network. The residual chlorine level was found between 0.2-0.4 ppm in outlet waters of waterworks, ideally, which should be about $0.7 \mathrm{ppm}$. It was concluded from the work of Tavakoli et al. (2005) that total chlorine levels of less than $0.71 \mathrm{mg} / \mathrm{l}$ in water supply systems could not provide the recommended safety levels. They have reported that Aeromonas hydrophila was get inactivated in $<100$ minutes time at chlorine levels of $0.11 \mathrm{mg} / \mathrm{l}$ to 0.90 $\mathrm{mg} / \mathrm{l}$; whereas. Escherichia coli were able to tolerate $0.30 \mathrm{mg} / \mathrm{l}$ chlorine for $>1,000$ minutes while Enterococcus faecalis and Salmonella typhi survived at total chlorine concentration of $0.50 \mathrm{mg} / \mathrm{l}$ for 100 minutes. The higher number of counts of total coliform also indicates chances of other bacterial contamination. Diarrhoeal diseases, jaundice and hepatitis, were observed at low levels in all age groups indicating that most of the water quality is improving except a few sites (on site-specific contamination). During the present study $5.0 \%$ prevalence of gastrointestinal diseases might be due to water pollution (Tabs. 1-2). Of all 1.2\% had abdominal pain, $0.3 \%$ diarrhoea, $0.3 \%$ dysentery, $0.7 \%$ gastritis, $0.6 \%$ jaundice, $0.4 \%$ typhoid, $0.3 \%$ hepatitis, and $0.4 \%$ had typhoid. Almost similar results was observed at Bikaner City in North-West Rajathan where $15.5 \%$ of the population and $44.5 \%$ of families suffered from one or more common water-borne diseases including amoebiasis, diarrhoea (5.4\%), dysentery, jaundice and typhoid (Saxena and Chhabra, 2004). The presence of total coliform, faecal coliform and faecal streptococci in household drinking water may be due to leakage of pipes, mixing of sewer wastewater with supply lines particularly in narrow and tight roads, or storage endpoints as tanks or earthen/brass vessels (mutkas) in households. Another factor responsible for it is intermittent water supply on alternate days, which also encourage bacterial growth in pipelines. Similar observations for drinking water were also reported by George et al. (2006) in Lebanon where intermittent water supply systems exist. The causes of pollution can also be predicted on the basis of the ratio of FC/FS (Tab. 8). It was inferred from the FC/FS ratio that household drinking water contamination is due to human pollution (Gerba, 2000; Gerba and Pepper, 2006; Gerba, 2009; Hass et al., 2014). 
Table 8: FC/FS ratio in all water samples and type of pollution (2004-2005) (*Gerba, 2000; 2009; 2015).

\begin{tabular}{|c|c|c|c|c|c|}
\hline $\begin{array}{c}\text { Water } \\
\text { source }\end{array}$ & FC/FS & FC/FS* & $\begin{array}{c}\text { Pollution } \\
\text { source* }\end{array}$ & $\begin{array}{c}\text { Water } \\
\text { source }\end{array}$ & FC/FS \\
\hline $\begin{array}{c}\text { Drinking } \\
\text { water } \\
\mathrm{N}=123\end{array}$ & 4.3 & $>4.0$ & $\begin{array}{c}\text { Human } \\
\text { pollution }\end{array}$ & $\begin{array}{c}\text { Drinking } \\
\text { water } \\
\mathrm{N}=123\end{array}$ & 4.3 \\
\hline $\begin{array}{c}\text { Filter } \\
\text { plant } \\
\mathrm{N}=6\end{array}$ & 1.4 & $2.0-4.0$ & $\begin{array}{c}\text { Human waste } \\
\text { in mixed } \\
\text { pollution }\end{array}$ & $\begin{array}{c}\text { Filter plant } \\
\mathrm{N}=6\end{array}$ & 1.4 \\
\hline $\begin{array}{c}\text { Raw } \\
\text { water } \\
\mathrm{N}=9\end{array}$ & 0.7 & $<0.7$ & $\begin{array}{c}\text { Animal } \\
\text { pollution }\end{array}$ & $\begin{array}{c}\text { Raw water } \\
\mathrm{N}=9\end{array}$ & 0.7 \\
\hline $\begin{array}{c}\text { Open/ } \\
\text { step wells } \\
\mathrm{N}=9\end{array}$ & 0.9 & $0.7-2.0$ & $\begin{array}{c}\text { Animal waste } \\
\text { in mixed } \\
\text { pollution }\end{array}$ & $\begin{array}{c}\text { Open/ } \\
\text { step wells } \\
\mathrm{N}=9\end{array}$ & 0.9 \\
\hline $\begin{array}{c}\text { Hand pumps/ } \\
\text { bore wells } \\
\mathrm{N}=23\end{array}$ & 7.3 & $>4.0$ & $\begin{array}{c}\text { Human } \\
\text { pollution }\end{array}$ & $\begin{array}{c}\text { Hand pumps/ } \\
\text { bore wells } \\
\mathrm{N}=23\end{array}$ & 7.3 \\
\hline
\end{tabular}

The results of household drinking water quality showed that all physical and chemical parameters were within the range of ICMR/WHO drinking water standards (Tabs. 1-2). Same is true for water samples of surface water sources and waterworks (Tab. 1).

Household drinking water supply was available to $85.6 \%$ population (89.8\% houses), and the remaining $14.4 \%$ population (10.2\% houses) depended on public taps or other improper water sources such as tankers, hand pumps, reservoirs, tube wells and open wells. The presence of total coliform, faecal coliform and faecal streptococci in all groundwater samples except the samples collected from the tube well indicates pollution in the groundwater aquifer in Jodhpur City. It indicates that groundwater contamination is also has link with seepage and leachate from sewerage, industrial effluents, industrial hazardous wastes, landfills and agricultural runoff. The same is not be the cause of higher concentration of nitrates, sulphates, chlorides, total hardness (calcium and magnesium), conductivity, and total dissolved solids as it is occurring naturally in a large area of western Rajasthan. Higher concentration of chloride content of water may also indicate possible pollution from human sewerage, animal manure or industrial wastes (APHA, 1998; CPCB, 2009). The higher concentrations of total dissolved solids (TDS) may cause adverse taste effects as highly mineralized water may also deteriorate domestic plumbing and appliances (APHA, 1998; CPCB, 2009). The presence of higher concentration of above-mentioned parameters also favours the bacterial contamination. Some studies carried out by Kumar et al. (2006) on drinking water drawn from hand pumps and tube wells at different locations in district Bathinda, Punjab had revealed a higher concentration of sodium, potassium, calcium, magnesium, chlorine and total hardness along with the $\mathrm{pH}$ value and conductivity of the water. Similar, observations of contaminations of drinking water drawn either from surface waters or groundwater by leaching from the soil were made by Holt (2000), and Reimann and Banks (2004). 
Groundwater samples from open wells/hand pumps and tube wells showed high levels of nitrates (124.6 mg/l, $296.1 \mathrm{mg} / \mathrm{l}$; Tab. 1). It was three-six times higher than the acceptable standard given by the World Health Organization (2005, 2007, 2008). Groundwater $\mathrm{NO}_{3}^{-}$ contamination in shallow unconfined aquifers in Jodhpur is occurring naturally through the use of industrial effluents and city sewerage for irrigation and land application of animal manures and inorganic, commercial fertilizers also increase its level through the leaching process. Many studies have documented the relationship between agricultural activities and $\mathrm{NO}_{3}^{-}$leaching in shallow aquifers (Power and Schepers, 1989; Spalding and Exner, 1993; Stuart et al., 1994; Puckett et al., 1999; Nolan and Stoner, 2000; Gupta et al., 2000; Nolan, 2001; Sandor et al., 2001; Kumar et al., 2002; Robert et al., 2003). The present results of the high level of nitrates in groundwater of Jodhpur City are also in line with the findings of major parts of Churu, Alwar, Bharatpur, Jalore, Jaipur, Sikar, Tonk, and Jhunjhunu districts of Rajasthan which are also inherited by nitrate-rich ground waters (Kumar et al., 2002). They have classified nitrate toxicity into five water quality zones, namely, safe, mild, moderately problematic, highly problematic and dangerous with a view of health effects. The groundwater nitrate has much increased in the last years, and the demonstration of endogenous nitration among highly exposed subjects raises the concern of elevated cancer risk. The high-level groundwater nitrates may be one of the causes of gastrointestinal cancers in the city, which have been observed (Tab. 7). Similar results regarding gastric cancers and its association of nitrate content were observed by Sandor et al. (2001) in a small area of inequalities. In the present study, history of diabetes was given by $2.1 \%$ of males and $2.2 \%$ of females but was not found among groundwater water users in Jodhpur (Tab. 5). Kostraba et al. (1992) have suggested that even low-level nitrate exposure through drinking water may play a role in the etiology of Insulin Dependent Diabetes Mellitus (IDDM).

Metals like lead, cadmium, and iron in household drinking water samples from supply during the study period were detected within the limit (Tab. 1). This can be inferred from the absence of heavy metal pollution in surface waters and water works outlets that it is potable and good for consumption. The presence of metals in household drinking water indicates pollution at endpoints that may be due to leakage of supply pipelines or storage tanks at household levels. Similar reports of Alam and Sadiq (1989) on metal contamination of drinking water in Dhahran found that copper, iron, and zinc in the drinking water increased during its transportation which was related to the length and material of distribution pipes and the concentration of copper and zinc were increased during overnight storage of water in the appliances. The absence of metals indicates ground waters that they may be absent in leachate or seepage from landfills, city sewer lines, hazardous waste effluent. Almost similar results were reported from Delhi region by Dixit et al. (2003) for drinking waters drawn from tube wells and surface waters where marginally high levels of manganese, copper, selenium, and cadmium than Indian Standards (IS) specification regulated for drinking water. The levels of iron, nickel, lead, and zinc were within limits (final water supply of four treatment plants; Dixit et al., 2003).

The main dumping ground for MSW is situated in the western part of the city. The percent fractions of the main components of municipal solid waste samples such as minerals and building material (29.25\%), glasses and porcelains (3.3\%), polythene bags, rubbers and plastics (3.8\%), fibers (textile and a part of waste wood, papers, vegetable matter, etc.) (3\%), metals with iron (2.2\%), compostable material (26.0\%), and fine soil with ash (32.5\%) were found during the present study (Tab. 3). Similarly percent fractions of municipal solid wastes reported in 40 cities by Bhinde and Sundaresan (1983) and 23 mega cities by EPTRI (1995) and were compared with the present status of MS in Jodhpur City. The difference lies in the 
presence of stones and building material (29.2\%), which seems to be absent in other cities in India. This may be due to the presence of sandstone quarries and mineral extractions industries in the city. The other important fraction was the presence of a lower amount of compostable matter and fine ash/soils as compared to other cities (Bhinde and Sundaresan, 1983; EPTRI, 1995). Present findings for plastics, fibbers (rags), glasses, and metals are almost the same as reported by EPTRI (1995) in mega cities. Bhinde and Subdersan (1983) has reported that the urban population generate $374 \mathrm{~g} / \mathrm{capita} /$ day of solid wastes whereas later on EPTRI (1995) has estimated about $456 \mathrm{~g} / \mathrm{capita} / \mathrm{day}$ of solid waste. According to their findings, it can be estimated that in Jodhpur the total amount of MSW generated per day will be between 374 to 456 tons per day. Each of urban residents generates 350-1,000 g solid wastes every day (Upadhyay et al., 2005). The high amount of non-degradable (9.3\%) and slow degradable fractions is a matter of public health concern. About $0.3 \%$ of the population was facing pollution problem due to solid wastes in their surroundings in Jodhpur City. Most houses (97\%) did not have any garbage disposal facility, and garbage from these houses was dumped on roadsides or open plots. It was found that toilets were not available in 5.9\% houses and these residents practiced open field defecation, whereas $0.1 \%$ individuals depended on common toilets meant for a group of families, $1.3 \%$ on dry pits and $3.3 \%$ on public toilets. In all $10.6 \%$ of houses in the city did not have easy access to sanitary facilities. All these might be the main cause of the significant prevalence $(4.1 \%, p<0.001)$ of skin disease. The poor sanitary facility, personal hygiene and lack of safe drinking water may cause health problems in the near future at a much larger scale due to the presence of contaminants, toxic metals and other pathogens.

\section{CONCLUSIONS}

The human health is adversely affected by the pollution of water and bad sanitation, which is more marked in developing countries like India. Presence of faecal coliform in 56\% and faecal streptococci in $42 \%$ water samples, indicating the microbial contamination (human pollution). The study indicates that low levels of diarrhoeal diseases (diarrhoea $0.3 \%$, dysentery $0.3 \%$, and gastritis $0.7 \%)$, jaundice $(0.6 \%)$, hepatitis $(0.3 \%)$, and typhoid $(0.4 \%)$ the improving health condition in all age groups. Except for a few sites all water samples from surface water, waterworks outlets and household drinking water as stored in tanks or earthenware vessels were found potable as their physical and chemical quality are concerned. Nitrates were three-six times higher in all groundwater samples $(124.6 \mathrm{mg} / \mathrm{l}$ and $296.1 \mathrm{mg} / \mathrm{l}$ respectively) than the drinking water standards given by WHO (2008). They can be the cause of elevated gastrointestinal cancer and diabetes mellitus. Electric conductivity, nitrate, $\mathrm{pH}$, chloride, calcium, sulphate, magnesium, cadmium, iron and lead were measured, all of these not exceed the drinking water standards but reveal pollution at endpoints that may be due to leakage of pipelines or storage tanks. Thus, increasing demand for safe drinking water may cause health problems in the near future at a much larger scale.

\section{ACKNOWLEDGEMENTS}

We are thankful to the Ministry of Environment and Forests, Government of India for sponsoring the project "Environmental Health Study in Jodhpur". 


\section{REFERENCES}

1. Ahern M., Kovats R., Wilkinson P., Few R. and Matthies F., 2005 - Global health impacts of floods: Epidemiologic Evidence, Epidemiologic Reviews, 27, 1, 36-46.

2. Alam I. A. and Sadiq M., 1989 - Metal contamination of drinking water from corrosion of distribution pipes, Environmental Pollution, 57, 167-178.

3. Benova L., Cumming O. and Campbell O., 2014 - Systematic review and meta-analysis: association between water and sanitation environment and maternal mortality, Tropical Medicine and International Health, 19, 4, 368-387.

4. Bhinde A. D. and Sundaresan B. B., 1983 - Solid waste management in developing countries, New Delhi, Indian National Scientific Documentation Centre, 222.

5. Central Pollution Control Board (CPCB), 2009 - Status of water quality in India, Monitoring of Indian Aquatic Resources Series, Minars/2009-2010, New Delhi.

6. Dixit R. C., Verma S. R., Nitnaware V. and Thacker N. P., 2003 - Heavy metals contamination in surface and groundwater supply of a city, Indian Journal of Environmental Health, 45, 107-112.

7. Eaton A. D., Clesceri L. S., Greenberg A. E., Greenberg A. E. and Franson M. A. H. $1998-$ Standard methods: for the examination of water and wastewater, 20th edition, American Public Health Association, Washington DC, 1220.

8. EPTRI 1995 - Status of solid waste disposal in Metropolis Hyderabad, Hyderabad, Environmental Protection Training and Research Institute, 46.

9. Fewtrell L., Kaufmann R. B., Kay D., Enanoria W., Haller L. and Colford J. M. Jr. 2005 Water, sanitation, and hygiene interventions to reduce diarrhoea in less developed countries: a systematic review and meta-analysis, Lancet Infectious Diseas, 5, 42-52.

10. Flörke M., Kynast E., Bärlund I., Eisner S., Wimmer E. and Alcamo J., 2013 - Domestic and industrial water uses of the past 60 years as a mirror of socio-economic development: A global simulation study, Global Environmental Change, 23, 1, 144-156, https://Doi.Org/10.1016/J.Gloenvcha.2012.10.018.

11. George M. and Ayoub L. M., 2006 - Impact of intermittent water supply on water quality in Lebanon, International Journal of Environment and Pollution, 26, 379-397.

12. Gerba C. P., 2000 - Indicator Organisms, 491-503, in Environmental Microbiology, Maier R. M., Pepper I. L. and Gerba C. P., (eds), Academic Press, San Diego, CA, 585.

13. Gerba C. P. and Pepper I. L., 2006 - Microbial contaminants, in Environmental and Pollution Science, 2nd edition, Pepper I. L., Gerba C. P. and Brusseau M. L. (eds), Academic Press, San Diego, CA, 144-169.

14. Gerba C. P., 2009 - Environmentally transmitted pathogens, 445-484, in Environmental Microbiology (2nd edition), Maier R. M., Pepper I. L. and Gerba C. P., (eds), Elsevier Academic Press, 589.

15. Gerba C. P., 2015 - Indicator microorganisms, VI, Water and foodborne pathogens, Chapter 23, 551-564, in Environmental microbiology, 3rd edition, Pepper I. L., Gerba C. P. and Gentry T. J., (eds), Elsevier Press, 728.

16. Ghosh A. B., Bajaj J. C., Hasan R. and Singh D., 1983 - Soil and water testing methods: a laboratory manual, IARI, New Delhi, 31-36.

17. Gjyli L. and Mukli L., 2009 - Assessment of water microbiologic pollution in Durres's marine harbour basin (Albania), Transylvanian Review of Systematical and Ecological Research, 8, The Wetlands Diversity, 169-184.

18. Greenberg A. E., Clesceri L. S. and Laton A. D. (eds) 1992 - Standard methods: for the examination of water and wastewater, 18th edition, American Public Health Association, Washington DC, ISBN-10: 0875532071, 1100.

19. Gupta S. K., Gupta R. C., Gupta A. B., Seth A. K., Bassin J. K. and Gupta A. 2000 - Recurrent acute respiratory tract infections in areas with high nitrate concentrations in drinking water, Environ Health Perspect, 108, 363-366.

20. Haas C. N., Rose J. B. and Gerba C. P., 2014 - Quantitative microbial risk assessment, 2nd edition, Wiley Blackwell, ISBN 9781118910030, 427. 
21. Haddeland I., Biemans H., Eisner S., Fekete B., Florke M., Hanasaki N., Heinke J., Ludwig F., Schewe J., Stacke T., Wada Y. and Wisser D., 2013 - A global multi-model view on water balance alterations caused by human interventions versus climate change, Proceedings of the National Academy of Sciences, submitted.

22. Holt M. S., 2000 - Sources of chemical contaminants and routes into the freshwater environment, Food Chemical Toxicology Journal, 38, 1 supplement S, 21-27.

23. Hutton G. and Haller H., 2004 - Evaluation of the costs and benefits of water and sanitation improvements at global level, Geneva, World Health Organization, 87, WHO/SDE/WSH/0404.

24. Hutton G., Haller L. and Bartram J., 2007 - Economic and health effects of increasing coverage of lowcost household drinking-water supply and sanitation interventions to countries off-track to meet MDG target 10, Geneva, World Health Organization, 68.

25. Hutton G. and Chase C., 2017 - Water supply, sanitation and hygiene, in Injury prevention and environmental health, disease control priorities, 3rd edition, 7, World Bank Group, 171-198.

26. Kostraba J. N., Gay E. C., Rewers M. and Hamman R. F., 1992 - Nitrate levels in community drinking waters and risk of IDDM, An ecological analysis, Diabetes Care, 15, 11, 1505-1508.

27. Kumar S., Gupta A. B. and Gupta S., 2002 - Need for revision of nitrates standards for drinking water: a case study of Rajasthan, Indian Journal of Environmental Health, 44, 168-172.

28. Kumar M., Singh S. and Mahajan R. K., 2006 - Mahajan Rk., trace level determination of U, $\mathrm{Zn}, \mathrm{Cd}, \mathrm{Pb}, \mathrm{Cu}$ in drinking water samples, Environmental Monitoring Assessment, 112, 283-292.

29. Kumar G. S., Kar S. S. and Jain A., 2011 - Health and environmental sanitation in India: issues for prioritizing control strategies, Indian Journal of Occupational and Environmental Medicine, 2011 September-December., 15, 3, 93-96, Doi: 10.4103/0019-5278.93196.

30. Lim S. S., Vos T., Flaxman A. D., Danaei G., Shibuya K., Adair-Rohani H., Amann M., Anderson H. R., Andrews K. G., Aryee M., Atkinson C., Bacchus L. J., Bahalim A. N., Balakrishnan K., Balmes J., Barker-Collo S., Baxter A., Bell M. L., Blore J. D., Blyth F., Bonner C., Borges G., Bourne R., Boussinesq M., Brauer M., Brooks P., Bruce N. G., Brunekreef B., Bryan-Hancock C., Bucello C., Buchbinder R., Bull F., Burnett R. T., Byers T. E., Calabria B., Carapetis J., Carnahan E., Chafe Z., Charlson F., Chen H, Chen J. S., Cheng A. T., Child J. C., Cohen A., Colson K. E., Cowie B. C., Darby S., Darling S., Davis A., Degenhardt L., Dentener F., Des Jarlais D. C., Devries K., Dherani M., Ding E. L., Dorsey E. R., Driscoll T., Edmond K., Ali S. E., Engell R. E., Erwin P. J., Fahimi S., Falder G., Farzadfar F., Ferrari A., Finucane M. M., Flaxman S., Fowkes F. G., Freedman G., Freeman M. K., Gakidou E., Ghosh S., Giovannucci E., Gmel G., Graham K., Grainger R., Grant B., Gunnell D., Gutierrez H. R., Hall W., Hoek H. W., Hogan A., Hosgood H. D. 3rd, Hoy D., Hu H., Hubbell B. J., Hutchings S. J., Ibeanusi S. E., Jacklyn G. L., Jasrasaria R., Jonas J. B., Kan H., Kanis J. A., Kassebaum N., Kawakami N., Khang Y. H., Khatibzadeh S., Khoo J. P., Kok C., Laden F., Lalloo R., Lan Q., Lathlean T., Leasher J. L., Leigh J., Li Y., Lin J. K., Lipshultz S. E., London S., Lozano R., Lu Y., Mak J., Malekzadeh R., Mallinger L., Marcenes W., March L., Marks R., Martin R., McGale P., McGrath J., Mehta S., Mensah G. A., Merriman T. R., Micha R., Michaud C., Mishra V., Mohd Hanafiah K., Mokdad A. A., Morawska L., Mozaffarian D., Murphy T., Naghavi M., Neal B., Nelson P. K., Nolla J. M., Norman R., Olives C., Omer S. B., Orchard J., Osborne R., Ostro B., Page A., Pandey K. D., Parry C. D., Passmore E., Patra J., Pearce N., Pelizzari P. M., Petzold M., Phillips M. R., Pope D., Pope C. A. 3rd, Powles J., Rao M., Razavi H., Rehfuess E. A., Rehm J. T., Ritz B., Rivara F. P., Roberts T., Robinson C., Rodriguez-Portales J. A., Romieu I., Room R., Rosenfeld L. C., Roy A., Rushton L., Salomon J. A., Sampson U., Sanchez-Riera L., Sanman E., Sapkota A., Seedat S., Shi P., Shield K., Shivakoti R., Singh G. M., Sleet D. A., Smith E., Smith K. R., Stapelberg N. J., Steenland K., Stöckl H., Stovner L. J., Straif K., Straney L., Thurston G. D., Tran J. H., Van Dingenen R., van Donkelaar A., Veerman J. L., Vijayakumar L., Weintraub R., Weissman M. M., White R. A., Whiteford H., Wiersma S. T., Wilkinson J. D., 
Williams H. C., Williams W., Wilson N., Woolf A. D., Yip P., Zielinski J. M., Lopez A. D., Murray C. J., Ezzati M., Al Mazroa M. A. and Memish Z. A., 2012 - A comparative risk assessment of burden of disease and injury attributable to 67 risk factors and risk factor clusters in 21 regions, 1990-2010: A systematic analysis for the global burden of disease study 2010, The Lancet, 380, 9859, 2224-2260.

31. Mitchell R. J., Babcock S. R., Gelinas S., Nanus L. and Stasney D. E., 2003 - Nitrate distributions and source identification in the Abbotsford-Sumas Aquifer, Northwestern Washington State Journal of Environmental Quality, 32, 789-800.

32. Morris R. D., 1995 - Drinking water and cancer, Environ Health Perspectives, 103, supplement 8, 225-232.

33. Nolan B. T., 2001 - Relating nitrogen sources and aquifer susceptibility to nitrate in shallow ground waters of the United States, Ground Water, 39, 290-299.

34. Nolan B. T. and J. D. Stoner, 2000 - Nutrients in ground waters of the conterminous United States, 1992-1995, Environmental Science and Technology, 34, 1156-1165.

35. Power J. F. and Schepers J. S., 1989 - Nitrate contamination of groundwater in North America, Agriculture Ecosystems and Environment, 26, 165-187.

36. Puckett L. J., Crowley T. K., Lorenz D. L. and Stoner J. D., 1999 - Estimation of nitrate contamination of an agro-ecosystem outwash aquifer using a nitrogen mass-balance approach, Journal of Environmental Quality, 28, 2015-2025.

37. Registrar General and Census Commissioner of India 2001 - Provisional Population Totals, Census of India, Paper 1, New Delhi.

38. Reimann C. and Banks D., 2004 - Setting action levels for drinking water: are we protecting our health or our economy (or our backs!)?, Science of the Total Environment, 332, 13-21.

39. Sandor J., Kiss I., Farkas O. and Ember I., 2001 - Association between gastric cancer mortality and nitrate content of drinking water: ecological study on small area inequalities, European Journal of Epidemiology, 17, 443-447.

40. Saxena M. M. and Chhabra C., 2004 - A status survey of common water-borne diseases in desert city Bikaner (NW Rajasthan, India), Journal of Communication Disorders, 36, 53-59.

41. Spalding R. F. and Exner M. E., 1993 - Occurrence of nitrate in ground water - A review, Journal of Environmental Quality, 22, 392-402.

42. Stuart M. A., Rich F. J. and Bishop G. A., 1994 - Survey of nitrate contamination in shallow domestic wells of the inner coastal plain of Georgia, Ground Water, 33, 284-290.

43. Tavakoli A., Yazdani R., Shahmansouri M. R. and Isfahani B. N., 2005 - Chlorine residual efficiency in inactivating bacteria from secondary contamination, in Isfahan, 2002, Eastern Mediterranean Health Journal, 11, 3, 425-434.

44. United Nations 2001 - World population prospects: The 2000 Revision, United Nations, Population Division, Department of Economic and Social Affairs, New York, 59.

45. Upadhyay V. P., Rajeswar P. M., Ajay S. and Khazan S., 2005 - Eco Tools for Urban Waste Management in India, Journal of Human Ecology, 18, 253-269.

46. Vörösmarty C. J., Green P., Salisbury J. and Lammers R. B., 2000 - Global water resources: Vulnerability from climate change and population growth, Science, 289, 284-288.

47. World Health Organization, 2005 - Weekly Epidemiological Record, 3 June 2005, 80th Year/3 Juin 2005, 80e Année No. 22, 80, 193-200.

48. World Health Organization (WHO), 2007 - Guidelines for drinking-water quality, Incorporation first addendum, 1, Recommendations, 3rd edition, WHO, Geneva.

49. World Health Organization, 2008 - Guidelines for drinking-water quality, 3rd edition incorporating the first and second addenda, 1, Recommendations; WHO Press, Geneva, 515.

50. WHO/UNICEF 2000 - Global water supply and sanitation assessment, report, Geneva, WHO and UNICEF, www.who.org and www.unicef.org.

51. Zhao H. X., Mold M. D., Stenhouse E. A., Bird S. C., Wright D. E., Demaine A. G. and Millward B. A., 2001 - Drinking water composition and childhood-onset Type 1 diabetes mellitus in Devon and Cornwall, England, Diabet Medicine, 18, 709-717. 